\title{
Ethmoiditis in Children in a Developing Community
}

\author{
Wilson IB Onuigbo* \\ Department of Pathology, Medical Foundation \& Clinic, Nigeria
}

Submission: September 01, 2018; Published: September 07, 2018

*Corresponding author: Wilson IB Onuigbo, Department of Pathology, Medical Foundation \& Clinic, Nigeria, Email: wilson.onuigbo@gmail.com

\section{Abstract}

Singular cases of ethmoiditis were those of a 5-week-old child and a neonate. From countries as far apart as Belgium, Canada, France, and Spain, there were contributions on children suffering from ethmoiditis. Therefore, this paper considers its manifestations among the Ibo ethnic group in Nigeria. The findings are deemed to be worthy of documentation.

Keywords: Ethmoid; Childhood; Inflammation; Types; Developing Community

\section{Introduction}

Ethmoiditis presents in several modalities. This includes involvement of a 5-week-old boy in UK [1], and of a neonate in Malaysia [2]. Elsewhere, older children are presented from countries as far apart as Belgium [3], Canada [4], France [5,6], and Spain [7]. Accordingly, this paper concerns children of the Ibo ethnic group [8], because they were included as in a histopathology data pool which was recommended by a Birmingham (UK) group in terms of facilitating epidemiological analysis [9].

\section{Investigation}

The Government of the Eastern Region of Nigeria provided at the erstwhile Capital, Enugu, a Pathology Laboratory manned by the author. Having insisted on receiving formol-saline specimens accompanied by epidemiological data, cases mounted up. Moreover, as the individual reports were preserved assiduously, cases could be displayed as shown below (Table 1).

Table 1: Epidemiological data on ethmoiditis in children.

\begin{tabular}{|c|c|c|c|c|}
\hline No & Initials & Age & Sex & Microscopy \\
\hline 1 & NM & 11 & F & Chronic cell infiltrates \\
\hline 2 & OO & 10 & M & Scattered chronic cell infiltrates \\
\hline 3 & NC & 12 & M & Papillary chronic inflamed process \\
\hline 4 & NI & 13 & M & Chronic cell infiltrates \\
\hline 5 & NC & 13 & M & Dense chronic cell infiltrates \\
\hline
\end{tabular}

\section{Results and Discussion}

What stood out in the local patients was chronic inflammation including the unusual papillary lesion. In contrast, all the foreign cases mentioned abscess formation [3-7]. In addition, there were 72 children in whom the problem was periorbital cellulitis
[10]. The favorable implication of this difference is that local patients came for treatment during a relatively earlier stage of the disease. This is commendable in a developing community. Most commonly, the ill inhabitants are blamed for late resort to hospitals for proper treatment [11].

\section{References}

1. Murray A, Albanasawy L, Morrissey MS (2000) Periorbital cellulitis secondary to ethmoiditis in a 5 year old child. Intl J Pediat Otorhinolaryngol 52(1): 101-103.

2. Reddy SC, Sharma HS, Mazidah AS, Darnal HK, Mahayidin M (1999) Orbital abscess due to acute ethmoiditis in a neonate. Intl J Pediat Otorhinolaryngol 49(1): 81-86.

3. Dewever M, Dfouny C, De Paepe E (1990) Ethmoiditis and its orbital complications in children. Rev Med de Bruxelles 11(3): 54-58.

4. Samad I, Riding K (1991) Orbital complications of ethmoiditis: BC Children's Hospital experience, 1982-89. J Otolaryngol 20(6): 400-403.

5. Francois M, Mariani Kurkdijian P, Dupont E, Bingen E (2006) Acute ethmoiditis in children, a series of 125 cases. Arch de Pediatrie 13(1): 6-10.

6. Rubin F, Pierrot S, Lebreton M, Contencin P, Couloigner V (2013) Drainage of subperiosteal orbital abscesses complicating pediatric ethmoiditis: Comparison between external and transnasal approaches. Intl J Pediat Otorhinolaryngol 77(5): 796-802.

7. Furio RG, Agullo GA, Fasheh YW (1996) Acute ethmoiditis: A review of 38 cases. Anales Espanoles de Pediatria 44(2): 129-132.

8. Basden GT (1966) Niger Ibos. Lond: Cass, England.

9. Macartney JC, Rollaston TP, Codling BW (1980) Use of a histopathology data pool for epidemiological analysis. J Clin Pathol 33(4): 351-355.

10. Ariyan S, Krizek TJ (1975) Tropical ulcers. Plast Reconstruct Surg 55(3): 324-329.

11. Weizman Z, Mussaffi H (1986) Ethmoiditis associated periorbital cellulitis. Intl J Pediat Otorhinolaryngol 11(2): 147-151. 


\section{Your next submission with Juniper Publishers} will reach you the below assets

- Quality Editorial service

- Swift Peer Review

- Reprints availability

- E-prints Service

- Manuscript Podcast for convenient understanding

- Global attainment for your research

- Manuscript accessibility in different formats

( Pdf, E-pub, Full Text, Audio)

- Unceasing customer service

Track the below URL for one-step submission https://juniperpublishers.com/online-submission.php 